\title{
PILIHAN PENGOBATAN PASIEN KANKER PAYUDARA MASA KEMOTERAPI: STUDI KASUS
}

\author{
Laili Rahayuwati*, Kusman Ibrahim, Maria Komariah \\ Fakultas Keperawatan Universitas Padjadjaran, Sumedang 45363, Indonesia \\ *Email:lailira2002@yahoo.com
}

\begin{abstract}
Abstrak
Kanker payudara memberi pengaruh pada status emosional perempuan, terutama pada usia reproduksi. Selama pengobatan, mereka mendapatkan pengalaman individu yang unik. Studi kasus ini bertujuan untuk mengeksplorasi pengalaman hidup pasien kanker payudara pada pemilihan terapi dan situasi lingkungan yang mendorong promosi kesehatan. Studi ini melibatkan 17 partisipan yang dipilih dengan purposive sampling. Pengumpulan data melalui wawancara mendalam dan penelusuran catatan arsip. Terdapat empat tema dominan, yaitu (1) Kanker merupakan konsep dan bagian dari legalitas sosial budaya yang berifat subjektif; 2) Pemilihan jenis terapi harus diterima/disepakati oleh keluarga dan sistem dukungan sosial; 3) Kondisi sakit kanker memberikan arti dalam kehidupan pasien; dan (4) Harapan untuk sembuh. Pasien seharusnya dipahami sebagai sebuah hubungan antara tubuh sebagai entitas fisik dan aspek-aspek lain seperti psikologis, sosial dan spiritual. Oleh karena itu, pembangunan semua aspek (fisik, psikologis, sosial, spiritual) sudah menjadi bagian dari pengalaman hidup perempuan dengan kanker payudara.
\end{abstract}

Kata Kunci: fase kemoterapi, kanker payudara, pemilihan pengobatan

\begin{abstract}
Choice of Treatments among Breast Cancer Patients during Chemotherapy: Case Study. Breast cancer has an $t$ influence on emotional status of women, especially in reproductive age women. During cancer treatments, the women have uniquely individual experienced. The purpose of this case study was (1) to explore life experienced by breast cancer patients, including the choice of treatments and surrounding situation which encourage for health promoting. The study involved 17 women selecting with purposive sampling. The data were collected through in-depth interviews and documents or archive records reviewing. Based on the thematic analysis, we found four predominant themes which emerged as regards to patients' experienced. It was namely (1) Cancer is concept and part of socio-cultural legality; (2) Choosing the therapies should be accepted by family and social support system; 3) Valuing cancer as the disease in life; 4) Hoping for recovery. We should understand the breast cancer patients as a connection between the body as a physical entity and other aspects such as psychological, social and spiritual. Therefore, the development of all aspects (physical, psychological, social, spiritual) has become part of the life experience of women with breast cancer.
\end{abstract}

Keywords: breast cancer patients, choice of treatments, the life of experience of illness

\section{Pendahuluan}

WHO (2013) menyatakan secara spesifik bahwa sekitar 508.000 perempuan meninggal karena kanker payudara pada tahun 2011. Di Indonesia, khususnya di RS Kanker Dharmais Jakarta, kasus kanker payudara juga terus meningkat, dari 221 kasus pada tahun 2003 menjadi 657 kasus pada tahun 2008 (Rumah Sakit Kanker Dharmais, 2014). Kondisi ini diperparah karena sebanyak 60-70\% pasien yang datang ke RS sudah berada pada kondisi stadium lanjut. Kanker payudara, umumnya terjadi pada kelompok perempuan pasca menoupause, tetapi saat ini banyak ditemukan pada usia yang muda, seperti kurang dari 25 tahun (Kementerian Kesehatan, 2015).

Kanker payudara pada perempuan akan memengaruhi eksistensi dan kesejahteraannya, baik 
secara fisik, emosional, psikologis, sosial, maupun spiritual. Dampak akan terasa lebih berat bila terjadi pada usia reproduksi karena berkaitan dengan seksualitas dan posisi perempuan sebagai istri dan ibu (Brousselle, et al., 2017; Murtiwi, Nurachmah, \& Nuraini, 2005).

Masalah yang dihadapi pasien kanker payudara baik dalam menentukan diagnosis maupun pemilihan terapi bersifat multidimensi, dengan banyak pertimbangan seperti masalah fisik, sosial, psikologis dan spiritual, tentunya finansial. Terlebih lagi, pasien dan keluarga seringkali tida memahami pentingnya deteksi dini kanker payudara atau jika penyakit sudah berada pada kondisi lanjut. Mereka juga mengalami kesulitan untuk memutuskan terapi, apakah menggunakan terapi modern atau terapi komplementer (Anggraeni, Ngatimin, \& Arsin, 2012; WHO, 2017; Wang, 2017).

Berkaitan dengan pelayanan kesehatan yang dipilih pasien, hampir $70 \%$ pasien kanker payudara mengalami putus kemoterapi dan banyak yang tidak melakukan kemoterapi pra-bedah setelah didiagnosis kanker payudara stadium awal dan lebih memilih perawatan alternatif (Aprianti, 2012). Selanjutnya, Hikmanti dan Ardian (2014) mengungkapkan bahwa motivasi pasien dalam menggunakan terapi komplementer atau alternatif adalah membantu tubuh dalam proses penyembuhan $(75 \%)$, meningkatkan sistem kekebalan tubuh (56\%), dan merasa berbuat sesuatu dalam terapinya $(56 \%)$. Selain itu, sebanyak $88 \%$ responden menyatakan menggunakan terapi komplementer atau alternatif dengan melakukan terapi medis dalam waktu yang sama.

Masyarakat menggunakan terapi komplementer dengan alasan keyakinan, keuangan, menghindari kandungan kimia dan dampak terhadap kesembuhan (Widyatuti, 2008). Terapi komplementer menjadi salah satu cara bagi tenaga kesehatan, dalam hal ini adalah perawat untuk menciptakan lingkungan yang terapeutik dengan menggunakan diri sendiri sebagai alat atau media penyembuh pasien dari masalah kesehatan (WHO, 2017). Pengertian terapi komple- menter dalam hal ini adalah terapi yang digunakan bersama-sama dengan terapi medis konvensional (Wang, 2017). Terapi komplementer, diantaranya adalah pengobatan herbal. Beberapa tahun terakhir di Indonesia, penggunaan obat herbal yang berasal dari fitokimia ditujukan tidak sekedar untuk suplemen gizi maupun kosmetik, namun juga untuk kepentingan pengobatan. Namun demikian, masyarakat lebih memilih kombinasi antara terapi kimia, seperti kemoterapi dengan pengobatan dengan herbal (Universitas Gajah Mada, 2012).

Penerapan kesehatan integratif, yaitu terapi konvensional dan komplementer di Indonesia sudah merambah ke institusi pelayanan kesehatan sesuai dengan amanat UU No 36 tahun 2009 tentang kesehatan, dan dalam PP 72 tahun 2012 tentang Sistem Kesehatan Nasional juga diatur pelayanan kesehatan tradisional alternatif dan komplementer yang dilaksanakan secara sinergi dan integrasi dengan pelayanan kesehatan ("Siapkan Pengobatan Tradisonal di RS", 2014). Namun demikian, masih banyak menimbulkan sikap pro dan kontra di kalangan profesional kesehatan.

Meninjau permasalahan yang berkaitan dengan kebutuhan pasien kanker payudara terhadap jenis terapi yang dipilih, perlu suatu kajian yang berbasis ilmu kesehatan yang bermanfaat untuk memahami proses menentukan pilihan terapi pasien kanker payudara dalam meningkatkan kualitas hidupnya, dan bagi profesional kesehatan penting untuk mengembangkan kemampuan dan kompetensi sesuai dengan kebutuhan pasien dan masyarakat.

\section{Metode}

Penelitian ini dirancang dengan menggunakan metoda kualitatif studi kasus, yaitu memfokuskan pada pasien yang datang ke rumah sakit rujukan, untuk menganalisis situasi dan kebutuhan yang diperlukan pasien kanker payudara di wilayah Provinsi Jawa Barat mulai pada tahap menduga atau merasakan gejala, pilihan, sampai memutuskan berobat. Penelitian sudah 
mendapatkan persetujuan etik dari Fakultas Kedokteran Universitas Padjadjaran dengan No. 277/UN6.C1.3.2/KEPK/PN/2015.

Populasi penelitian ini adalah pasien yang sedang menjalani rawat inap maupun rawat jalan di RS yang telah didiagnosis kanker payudara. Sejumlah 17 pasien dipilih secara purposeful untuk mengetahui pandangan dan pengalaman dalam terapi kanker payudara. Adapun kriteria partisipan adalah yang sudah didiagnosis kanker payudara berdasar catatan medis; berasal dari wilayah Jawa Barat yang datang ke RS rujukan; dan pernah atau sedang menjalani kemoterapi.

Pengumpulan data dilakukan dengan wawancara mendalam, studi dokumentasi, dan data arsip. Adapun tahap wawancara mendalam yang akan dilakukan adalah: (1) Thematizing, mengapa dan apa yang sudah dan akan diteliti;

(2) Designing, merencanakan wawancara dalam penelitian; (3) Interviewing, melakukan wawancara berdasarkan pedoman yang sudah disusun; (4) Transcribing, menyiapkan hasil wawancara untuk dianalisis; (5) Analyzing, memutuskan tujuan, topik proses alamiah dari wawancara serta metode analisis yang sesuai; (6) Verifying, melakukan validasi dari hasil wawancara; (7) Reporting, membuat laporan sesuai dengan kriteria studi yang sudah dilakukan.

Validitas dan reliabilitas data dipertahankan dengan empat pengukuran, yaitu: (1) kredibilitas yang dipastikan melalui wawancara berulang untuk menyesuaikan yang disampaikan partisipan dengan situasi yang ada, (2) transferabilitas, data yang dikumpulkan memungkinkan untuk menggambarkan situasi pasien kanker di Jawa Barat, (3) dependabilitas, setiap tahap kualitatif dikuti, dari pendekatan ke pasien, pengumpulan data, sampai pengambilan kesimpulan, (4) konfirmabilitas, dilakukan triangulasi data dengan memperoleh informasi dari petugas tentang kondisi pasien. Adapun proses analisis data dari hasil transkrip dan observasi serta catatan medis dilakukan dengan menggunakan analisis tema.

\section{Hasil}

Latar belakang partisipan mencakup suku, pendidikan, dan social ekonomi. Semua bersuku Sunda, tetapi satu Jawa dan satu Sumatera. Mayoritas SMP dan SMA, satu D3 dan satu Sarjana. Mayoritas menegah ke bawah, tiga orang tinggi. Melalui kajian tematik, terdapat tema utama yang didapatkan berkenaan dengan persepsi pasien kanker terhadap penyakitnya serta pemilihan terapi pada saat mendapatkan gejala penyakit.

Lima tema utama yang didapatkan, yaitu: (1) Konsep penyakit berdasarkan kategori subyektif dan sosial budaya (illness, sickness); (2) Pilihan pengobatan yang diterima oleh keluarga; (3) Persepsi kesembuhan pada setiap jenis pengobatan; (4) Konsep sakit dalam kehidupan mempunyai makna positif; dan (5) Tingginya harapan sembuh. Adapun beberapa penjelasan tema yang muncul adalah sebagai berikut:

\section{Penyakit adalah faktor subyektif (yang dirasakan) dan dilegalisasi oleh budaya.} Hampir semua partisipan mengungkapkan sebenarnya mereka merasakan gejala kanker relatif sudah lama, bahkan 8-10 tahun yang lalu. Umumnya yang dirasakan pada awalnya adalah benjolan yang kecil saja di sekitar payudara. Hanya sedikit pasien sudah menduga menyampaikan kemungkinan kanker payudara. Namun, umumnya semua gejala dan tanda yang dirasakan tadi akan diabaikan atau tidak diperiksakan ke dokter. Hal ini disebabkan oleh beberapa kemungkinan: 1) kekawatiran akan mengetahui kejadian sebenarnya bahwa pasien menderita penyakit yang parah; 2) tidak mau menambah atau mengakibatkan rasa was-was pada diri pasien sendiri maupun keluarga ika mengetahui apa yang dideritanya; 3) keterbatasan biaya, jika benar didiagnosis penyakit parah belum atau tidak mempunyai biaya untuk berobat.

Secara umum, partisipan menilai benjolan yang ada adalah hal yang belum perlu untuk diperiksakan karena dalam kehidupan sehari-hari mereka masih mampu untuk beraktifitas seperti biasa. 
Baik aktifitas bekerja mencari penghasilan di luar rumah maupun aktifitas sehari-hari yang berkaitan dengan pekerjaan rumah tangga. Berdasarkan hal tersebut, sepanjang tidak mengganggu aktifitas, maka sesuatu gejala atau tanda bukanlah suatu penyakit. Hampir seluruh pasien menyatakan tidak memeriksakan gejala benjolan tersebut ke dokter atau RS.

Terlebih lagi, pengetahuan pasien tentang kanker sangat terbatas, umumnya mereka hanya mendapatkan sedikit informasi melalui televisi, selain itu hampir tidak pernah pasien mengetahui seluk beluk kanker dengan lebih detail. Informasi lain tentang kanker mereka dapatkan juga dari sumber yang dianggap dipercaya seperti, suami, saudara, teman maupun tetangga. Seringkali pula setiap gejala yang dirasakan oleh pasien dikonsultasi ke pemimpin informal, seperti orang yang tahu tentang agama, misal ustadz untuk memutuskan pertolongan atau mencari jenis pengobatan yang tepat.

Secara umum pasien tidak bermasalah dalam biaya pengobatan karena ditanggung melalui Gakinda dan BPJS. Bagi pasien yang sudah sakit sebelum periode BPJS atau asuransi lain (sebelum tahun 2011) mereka menyiapkan biaya pengobatan tersendiri, contohnya untuk sekali operasi menyiapkan dana 25-35 juta rupiah.

"Sebelum ikut BPJS untuk satu kali kemoterapi mencapai 2.5-3 juta, total operasi 23 -35 juta. Terus apa yang harus saya lakukan? Uangnya tidak ada, sudah habis. Ada beberapa orang yang mengatakan untuk tidak melakukan operasi, lebih baik menggunakan pengobatan herbal. Kemudian ibu mencoba mencari pengobatan herbal, adanya yang mahal dan ibu tidak sanggup karena memang tidak ada biayanya. Berhubung sudah ikut ada program BPJS dan ibu sudah tidak kuat karena selalu ada perdarahan, akhirnya ibu memutuskan untuk di kemoterapi di RS." (I-1)

Pilihan pengobatan yang diterima oleh keluarga. Hampir seluruh pasien menyatakan bahwa mereka tidak menentukan pilihan pengobatan sendiri atau mandiri. Setiap pilihan jenis pengobatan merupakan hasil diskusi dan kesepakatan dengan keluarga atau orang terdekat. Mayoritas pasien menyatakan bahwa orang yang paling berperan dalam pilihan pengobatan adalah suami, disusul keluarga seperti kakak dan adik perempuan. Dalam hal pilihan pengobatan, anak jarang sekali dilibatkan sekalipun beberapa diantara mereka sudah dewasa. Namun ada sedikit pasien yang menyatakan bahwa dukungan pilihan pengobatan mereka terima juga dari anak yang sudah dewasa. Yang berperan dalam menentukan pilihan pengobatan selanjutnya adalah pemimpin informal, yaitu orang yang dianggap tahu lebih baik dalam persoalan agama maupun dalam kehidupan sehari-hari, seperti ustadz, maupun keluarga yang berpendidikan apakah dokter maupun non dokter.

Situasi menunjukkan bahwa sulit bahkan tidak mungkin bagi pasien untuk menentukan pilihan pengobatan sendiri tanpa pertinmbangan orang lain. Hal ini disebabkan karena: 1) Karakter sosial dan budaya di masyarakat umumnya bersifat kolektif, sehingga setiap keputusan yang dianggap penting harus dihasilkan oleh kesepakatan bersama; 2) Pada tahap pasien mendapatkan diagnosis sakit dan mendapatkan pengobatan kemoterapi, akan terjadi penurunan fisik. Saat ini kehadiran dan support keluarga sangat dibutuhkan untuk menopang aktifitas fisik pasien. Bahkan ada pasien saat awal didiagnosis kanker, maka oleh suami yang menilai bahwa kanker adalah penyakit berat maka serta merta tidak diperbolehkan untuk melakukan pekerjaan rumah tangga. Lebih banyak disarankan untuk istirahat dan melakukan pekerjaan ringan saja. Sumber informansi menyatakan:

"Informasi yang saya tahu bahwa penyakit nya adalah penyakit mematikan. Setelah tahu itu ibu sangat drop, yang menjadi penyemangat ibu adalah jangan terlalu dipikirkan, yang terpenting adalah saya berusaha untuk berobat semampu kita, allhamdulillah badan ibu tidak drop, badan tidak mengecil. Suami tidak memperbolehkan mengerjakan yang berat, banyak istirahat." (I-4) 
Sumber informasi untuk pengobatan umumnya dilakukan melalui proses pencarian secara mandiri oleh keluarga. Baik melalui televisi, media maupun pencarian di internet. Ada juga partisipan yang menanyakan masalah penyakitnya dan proses pengobatan kepada dokter, namun sedikit pasien yang puas dengan jawaban yang diberikan. Selanjutnya, untuk jenis obat dan penggunaannya, umumnya mereka mendapatkan informasi dari perawat kemoterapi. Contoh ungkapan:

"Iya dia (suami) mah nyari nya di google di internet. Kata suami saya ini mungkin kanker lah gitu. Dia langsung bikinlah BPJS gitu. Takut sih sebelum saya dapet persiapan dulu, hmmh., dia langsung lah bikin BPJS gitu." (I-6)

"iya nyari di internet, ibu juga dapet informasi dari temen. Eh bukan temen tapi saudaranya teman. Terus ibu juga sebelum di operasi sama di kemo teh ke perwat dan dokter dulu nyari informasi." (I-16)

\section{Persepsi kesembuhan pada setiap jenis} pengobatan. Setiap pilihan pengobatan yang dilakukan oleh pasien, selalu bertujuan untuk kesembuhan. Berdasarkan pernyataan pasien, yang melakukan pilihan pengobatan Complementary Alternative Medicine (CAM) sebagian menyatakan bahwa bisa mengecilkan benjolan kanker, meskipun belum sembuh sepenuhnya. Namun sebagian pasien lain menyatakan bahwa pilihan pengobatan CAM belum mampu menyembuhkan penyakitnya. Adapun setiap pilihan pengobatan CAM umumnya dilandasi oleh: 1) Ketakutan terhadap konsep operasi pengobatan konvensional serta efek kemoterapi yang dinilai mempunyai dampak besar dari penurunan fisik; 2) Bebebara pasien menyatakan bahwa pilihan CAM juga didasarkan pada ketersediaan biaya. Meskipun jika dihitung secara total jumlah yang dikeluarkan untuk membiayai pengobatan melalui CAM (termasuk transportasi) maupun melalui medis konvensional adalah sama besar, namun dengan pilihan CAM mereka membayarkan sedikit demi sedikit sesuai dengan ketersediaan dana yang ada pada saat itu sehingga tidak dirasakan sangat memberatkan.
Dalam menentukan pilihan untuk menjalani pengobatan medis konvensional mempertimbangkan kerugian antara lain adalah: 1) Yang paling 'menakutkan' untuk tidak dipilih adalah operasi, karena secara fisik payudara merupakan salah satu citra perempuan sehingga jika harus diambil dengan operasi ada kekhawatiran besar bahwa pasien akan kehilangan ciri fisik sebagai perempuan secara utuh; 2) Menjalani kemoterapi, paling dirasakan besar dari segi efeknya, bukan sekedar mual dan muntah namun yang sangat dirasakan adalah kerontokan dan kebotakan rambut, penurunan badan secara drastis, penurunan fisik dan kehitaman warna kulit.

Meskipun, sebagian kecil partisipan mampu bertahan menjalani efek kemoterapi dengan melakukan pilihan diet dengan disiplin tinggi namun sebagian besar pasien merasakan pengalaman paling 'drop' secara fisik setelah menjalani kemoterapi. Beberapa pernyataan yang disampaikan oleh sebagian besar pasien berikut:

"Rasanya mual, ga bisa makan, ga bisa minum, saya ngedrop pertama kali dikemo. Jadwal berikut sudah datang lagi, saya ga kuat, ngedrop harus dirawat dulu. Harus makan bergizi dulu baru bisa dikemo lagi."

"Buat saya, di kemo paling berat (dibandingkan radiasi, operasi_red), banyak keluhannya setiap di kemo: meriang, sariawan, bahkan sakit kena mata."

Selain itu: "Efek kemo lebih berat dari radiasi dan operasi, sampe makan lidah juga ga ada rasa. Dan yang tidak bisa dilupakan kerontokan rambut sampe botak".

Dalam memandang efek kemoterapi, tiap partisipan mempunyai konsep yang variatif. Namun dalam melihat proses kesembuhan yang akan mereka terima setelah kemoterapi hampir seluruh subyek menyatakan secara positif mereka mempunyai harapan untuk sembuh setelah 'berjuang' dengan cara menjalani kemoterapi.

Biasanya pasien mulai menerima episode setiap perjalanan penyakit kanker payudara setelah pasien saling bertemu muka, bertukar pikiran 
dengan sesama pasien kanker baik dalam ruang kemoterapi maupun di luar ruang kemoterapi. Seperti contohnya, beberapa pasien rujukan ke RSHS dari beberapa tempat di luar kota Bandung seperti Purwakarta, Cianjur, Pengalengan, Tasikmalaya dan lainnya akan menyewa sebuah rumah 'kost' di sekitar lingkungan RS. Rumah tersebut memang kebanyakan dihuni oleh pasien yang menjalani kemoterapi di RSHS. Bahkan ibu kost sudah biasa menyiapkan bubur kacang hajau maupun bubur makanan untuk pasien yang datang. Jika biasanya kemoterapi dilaksanakan mulai jam 9-12 siang, makasebagian besar pasien akan datang ke tempat kost tersebut sehari sebelumnya untuk melakukan proses administrasi. Setelah proses administrasi selesai, maka esoknya mereka akan menjalani kemoterapi. Beberapa pasien langsung pulang ke luar kota setelah kemoterapi dengan memesan travel. Namun, ada sedikit pasien yang baru pulang keesokan harinya setelah menjalani kemoterapi. Di tempat kost inilah juga merupakan tempat untuk saling bertukar pikiran dan berdiskusi oleh sesama pasien kanker payudara yang umumnya datang ditemani suami atau kerabat lain.

\section{Konsep sakit dalam kehidupan mempunyai} makna positif. Meskipun pada awalnya, keberadaan sakit dianggap sebgai musibah oleh seluruh pasien. Bahkan sebagian dari mereka masih sering menyangkal. Namun, sebagian lain menilai bahwa sakit adalah suatu hal yang merupakan ujian Allah untuk setiap umatnya. Hal yang menunjukkan bahwa sakit memunyai nilai dalam kehidupan antara lain beberapa pernyataan yang menyebutkan: 1) Bisa jadi seorang pasien mempunyai beberapa kesalahan dan dosa yang harus ditebus dengan sakit mereka; 2) Dengan sakit mereka harus mengambil hikmah bahwa pasien diminta untuk belajar ihlas dan sabar dalam menerima semua takdir dan ketentuan Allah; 3) Dengan sakit, diharapkan mereka termotivasi dan berusaha untuk sembuh sebagai bentuk usaha dan ihtiar kepada Allah. Dengan sakit pula, pasien akan menjadi semakin dekat ke Allah karena selalu memohon unuk riringankan sakitnya. Keadaan sakit dan kesembuhan juga dinilai bervariasi menurut pasien, namun sebagian dari pasien menyatakan:

"Soal sembuh tergantung, ada keinginan sembuh ga, jika ada keinginan sembuh pasti bisa. Kaya kata dokter mah latihan tenang, enjoy aja. Masa mau jerit-jerit ke Allah, da tetep ga bisa sembuh. Jadi terima aja dengan ikhlas, mudah-mudahan bisa jadi obat."

"Kemo pertama juga awalnya sedikit down, tapi sekarang ngga, ya kalau pusing mual mudahmudahan dikuatkan saja sama Allah, sekarang ah jalani aja, enjoy-enjoy aja. Lebih deket sama Allah yang utama. Lihat pasien lain juga bisa, insya Allah."

Beberapa hal yang dirasakan oleh partispan sebagai kekurangan bahwa selama sakit, mereka tidak bisa menjalankan peranan pekerjaan di rumah tangga bahkan bisa jadi memberatkan menambah beban pekerjaan anggota keluarga lain. Ada partisipan yang sangat menerima keadaan sakitnya mencoba untuk melakukan evaluasi sebab sakit yang dialaminya:

"... mungkin pengaruh dari makanan terus karena saya kerja dan kepengaruh KB."

Namun, sedikit pasien yang masih sulit menerima sakitnya, sehingga tidak mau melakukan evaluasi, sebagaimana pernyataan berikut:

“... ada beberapa teman kerja yang meng-ajak mengikuti seminar kanker. Tapi ibu sudah menutup telinga. Ibu suka disuruh ikut seminar, tapi ibu merasa sudah tidak mau mendengarkan lagi, sudah cukup drop."

Hal positif lain adalah keberadaan teman berbagi, umumnya partisipan merasa mempunyai harapan besar dan merasa lebih baik saat melihat keberadaan sesama pasien kanker lain yang kurang beruntung secara fisik, bahkan seringkali lebih buruk kondisinya. Terlebih lagi, secara psikologis, sebagian besar partispan menyatakan bahwa diri mereka semakin kuat karena ada banyak orang yang menghibur dan memberikan dukungan positif. Sebagaimana pernyataan berikut: 
"Penyakit mah ga usah dipikirin yang penting mah dibawa enjoy. Kan disini mah banyak yang seumuran, kan kalau kontrol bareng, bekel timbel, makan-makan."

Salah satu partisipan yang berumur 81 tahun sekarang, merupakan penyintas kanker yang pernah dialami sepuluh tahun yang lalu menyatakan, bahwa untuk sembuh dimulai dari pola pikir, dimana pikiran harus berubah yang ada hanyalah motivasi untuk sembuh saja. Dan selalu mednekatkan diri pada Allah sepanjang waktu dengan cara meningkatkan ibadah mulai dari pagi hari sampai malam. Partisipan ini juga menyatakan, meskipun dalam kondisi yang dinyatakan sakit, karena profesinya sebagai guru, beliau tetap mengajar ke sekolah yang jaraknya $60 \mathrm{~km}$ pp ditempuh menggunakan bis kota.

Tingginya harapan sembuh. Meskipun soal kesembuhan terletak di tangan Allah, namun semua partisipan menyatakan mereka punya harapan besar untuk sembuh. Mereka selalu mohon doa untuk disembuhkan. Sekalipun secara usaha yang dibuktikan oleh masing-masing partisipan sangat bervariasi. Contohnya, sedikit pasien yang berusaha untuk memenuhi kebutuhan nutrisi dengan tepat dan jumlah yang cukup dengan 'melawan' nafsu makan yang sudah berkurang drastis. Di sisi lain, kebanyakan partisipan mengatakan kerena nafsu makan semakin menurun maka sulit bagi mereka unutk memenuhi kecukupan gizi yang seharusnya.

Hanya sedikit partisipan yang tahu bahwa kesembuhan penyakit kanker membutuhkan waktu yang sangat lama, bahkan selang lima tahun berlaku masih juga membutuhkan obat. Seperti halnya yang disampaikan partisipan berikut:

“... banyak gitu ya orang lain juga udah pada sehat cuman kalau sembuh total mah ee susah gitu yak arena masih harus terus berobat kan. Kan kanker mah yang udah 5 tahun juga harus terus berobat."

Tentang harapan sembuh, salah seorang partisipan yang mempunyai harapan untuk menuaikan ibadah lebih baik. Partisipan lain menya- takan jika sembuh ingin membuka usaha untuk membantu perekonomian keluarga di masa depan.

\section{Pembahasan}

Secara umum, partisipan menentukan pilihan berobat tidak sekedar pada medis modern, namun banyak memanfaatkan terapi yang bersifat alternatif maupun komplementer. Menurut WHO (2017), pengobatan komplementer adalah pengobatan non konvensional yang bukan berasal dari negara yang bersangkutan, namun kriteria ini juga perlu dirumuskan kembali karena terapi herbal di Indonesia justru sebagian besar merupakan terapi komplementer. Tambahan definisi tentang terapi komplementer adalah semua terapi yang digunakan sebagai tambahan untuk terapi konvensional yang direkomendasikan oleh penyelenggaraan pelayanan kesehatan individu (Potter \& Perry, 2009). Selain itu, CAM diartikan sebagai suatu bentuk penyembuhan yang bersumber dari berbagai sistem, modalitas dan praktek kesehatan, baik yang didukung secara teori maupun dari kepercayaan (WHO, 2017; Wang, 2017).

Berdasarkan pandangan partisipan, mereka sulit membedakan apakah pilihan berobat mereka bersifat alternatif ataupun komplementer. Idealnya, partisipan perlu memahami perbedaan antara terapi komplementer dan terapi alternatif. Jika terapi komplementer (komplemen= pelengkap), diartikan sebagai terapi pelengkap dari terapi konvensional yang telah dibuktikan manfaatnya. Maka terapi alternatif adalah penggunaan terapi diluar sistem konvensional. Meskipun terapi alternatif meliputi intervensi yang sama dengan terapi komplementer, tetapi sering kali yang dilakukan pasien saat pemilihan pengobatan awal adalah terapi alternatif menjadi pengobatan primer yang mengganti pelayanan medis (Wang, 2017).

Keperawatan komlementer adalah cabang ilmu keperawatan yang menerapkan pengobatan non konvensional yang ditujukan untuk meningkatkan derajat kesehatan masyarakat meliputi 
upaya promotif, preventif, kuratif dan rehabilitatif. Upaya yang dilakukan tersebut bertujuan untuk mengontrol gejala, meningkatkan kualitas hidup, dan berkontribusi terhadap penatalaksanaan pasien secara keseluruhan. Sehingga diperlukan adanya pendidikan terstruktur dengan kualitas, keamanan dan efektifitas yang tinggi berlandas ilmu pengetahuan biomedik (Frisch, 2001; Irawan, Rahayuwati, \& Yani, 2017).

Masalah fisik yang muncul antara lain hilangnya nafsu makan setelah mendapat kemoterapi atau terapi radiasi. Hal tersebut sejalan dengan kesimpulan penelitian Yabroff, et al., (2004) bahwa meskipun klien kanker payudara hidup lebih lama, mereka belum tentu sehat seperti masyarakat umum lainya. Berbagai upaya informan lakukan untuk memenuhi kebutuhan nutrisi agar kondisi fisiknya tetap stabil, baik melalui upaya pemenuhan sesuai anjuran medis maupun pencarian ke terapi alternatif dan komplementer.

Selain kebutuhan pengobata yang bersifat fisik, secara umum pasien sangat membutuhkan kebutuhan psikologis dan sosial. Gangguan psikologis termasuk kecemasan dan depresi, umumnya terjadi pada pasien kanker dengan berbagai diagnosa dan mereka mencoba bertahan dari waktu ke waktu (Kim, et al., 2015). Hasil sebuah penelitian memperkirakan bahwa depresi telah terjadi pada 20-25\% dari pasien kanker dan tampaknya lebih tinggi pada pasien dengan kanker stadium lanjut (Redeker, Lev, \& Ruggiero, 2000). Diagnosis kanker payudara juga meningkatkan distres psikososial bagi penderitanya (Mahon, 2011). Kebutuhan emosional dan sosial pasien bisa dilakukan dan diperoleh melalui interaksi dan semua dukungan, terutama oleh keluarga dalam bentuk dukungan emosional (perhatian, kasih sayang, empati), dukungan penghargaan (menghargai kondisi pasien yang masih dalam perawatan, memberikan umpan balik sesuatu yang dibutuhkan atau lainnya), dukungan informasi (saran, nasehat) maupun dukungan instrumental (melalui ketersediaan tenaga, dana dan waktu). Penelitian yang dilakukan oleh Kroenke, et al. (2013) mengung- kapkan bahwa selain dukungan keluarga, ada hubungan antara jaringan sosial dan mekanisme dukungan sosial terhadap kualitas hidup penderita kanker setelah didignosa. Dukungan sosial bisa berasal dari teman, tetangga dan komunitas. Kebutuhan spiritual juga ditunjukkan oleh pasien, sehingga dukungan spiritual harus dikuatkan terutama untuk mendukung sistem fisik dan psikologis melalui bantuan kesembuhan pasien dengan selalu mengajak berpikir positif, menjalani hidup penuh arti dan mampu bertahan terhadap penyakitnya (Witdiawati, Rahayuwati, \& Sari, 2017).

Mengingat, tingginya kebutuhan pasien kanker payudara terhadap terapi komplementer, diharapkan perawat mampu melakukan pendekatan secara holistik (bio, psiko, sosio, kultural, spiritual) kepada pasien dalam penanganan penggunaan terapi. Secara khusus, perawat bekerja sangat dekat dengan klien mereka dan berada dalam posisi mengenali titik pandang klien. Oleh karena itu, diharapkan perawat mampu menentukan terapi medis alternatif atau komplementer mana yang lebih sesuai dengan kepercayaan dan menawarkan rekomendasi yang sesuai dengan kebutuhan pasien kanker payudara (Potter \& Perry, 2009).

\section{Kesimpulan}

Pasien kanker payudara selalu dipahami sebagai kondisi bahwa manusia adalah kompleks, terdisiri dari keterikatan tubuh secara fisik, serta aspek lain seperti psikologi, sosial budaya dan spiritual. Oleh karena itu, perjalanan hidup dalam sebagai pasien kanker payudara sebagai pengalaman sakit selalu melibatkan unsur fisik, psikologis, social budaya dan spiritual.

Perjalanan hidup pasien kanker dalam mencari pilihan terapi harus dimaknai dalam pemahaman sudut pandang pasien dan keluarga itu sendiri. Sehingga para petugas kesehatan harusnya mampu memberikan perawatan dan terapi lebih spesifik sesuai kebutuhan pasien (SS, YA, INR). 


\section{Referensi}

Anggraeni, R., Ngatimin, R., \& Arsin, A. (2012). Deteksi dini pada penderita kanker payudara stadium lanjut di RSUD Labuang Baji Makassar. Diperoleh dari http://pasca.unhas. ac.id/jurnal/files/7599e1c4c12fbfbb9d41626 7405f4c63.pdf

Aprianti, D. (2012). Faktor-faktor yang berhubungan dengan pencarian pelayanan kesehatan pada pasien kanker payudara di RSUP Dr. Hasan Sadikin Bandung (Skripsi, tidak dipublikasikan). Program Sarjana Universitas Pendidikan Indonesia, Bandung.

Brousselle, A., Breton, M., Benhadj, L., Tremblay, D., Provost, S., Roberge, D., . . . Tousignant, P. (2017). Explaining time elapsed prior to cancer diagnosis: Patients perspectives. BMC Health Services Research, 17 (1), 448. doi: 10.1186/s12913-017-2390-1.

Frisch, N. (2001). Nursing as a context for alternative/ complementary modalities. Online Journal of Issues in Nursing, 6 (2), 2.

Hikmanti, \& Adrian, F.H.N. (2014). Analisis Faktor-faktor yang mempengaruhi keterlambatan pengobatan pada wanita penderita kanker payudara. Prosiding Seminar Nasional Hasil-Hasil Penelitian \& Pengabdian. Diperoleh dari http://jurnal.unimus.ac.id/ index.php/psn12012010/article/view/1253/1 306.

Irawan, E., Rahayuwati, L., \& Yani, D. (2017). Hubungan penggunaan terapi modern dan komplementer terhadap kualitas hidup pasien kanker payudara. Jurnal Keperawatan Padjadjaran, 5 (1), 19-28.

Kementerian Kesehatan RI. (2015). Pusat Data dan Informasi Kementerian Kesehaan RI. Jakarta: Kementerian Kesehatan RI.

Kim, M.K., Kim, T., Moon, H.G., Jin, U.S., Kim, K., Kim, J., ... Han, W. (2015). Effect of cosmetic outcome on quality of life after breast cancer surgery. European Journal of Surgical Oncology, 41 (3), 426-432, https:// doi.org/10.1016/j.ejso.2014.12.002.
Kroenke, C.H., Kwan, M. L., Neugut, A.I., Ergas, I.J., Wright, J.D., Caan, B.J., . . Kushi, L.H. (2013). Social networks, social support mechanisms, and quality of life after breast cancer diagnosis. Breast Cancer Research and Treatment, 139 (2), 515-527. doi: 10.1007/s10549-013-2477-2.

Mahon, S.M. (Ed.) (2011). Breast cancer. Pittsburgh, US: Oncology Nursing Society. Diperoleh from http://www.ebrary.com.

Murtiwi, M., Nurachmah, E., \& Nuraini, T. (2005). kualitas hidup klien kanker yang menerima pelayanan hospis atau homecare: Suatu analisis kuantitatif. Jurnal Keperawatan Indonesia, 9 (1), 13-18. doi: http://dx.doi. org/10.7454/jki.v9i1.154

Potter, P., \& Perry, A. (2009). Fundamental of nursing (3rd Ed.). Toronto, ON: Elsevier Canada.

Redeker, N.S., Lev, E.L., \& Ruggiero, J. (2000). Insomnia, fatigue, anxiety, depression, and quality of life of cancer patients undergoing chemotherapy. Scholarly Inquiry for Nursing Practice, 14 (4), 275-284, 286-290.

Rumah Sakit Kanker Dharmais. (2014). Statistik kanker: 10 besar kanker tersering RSKD rawat jalan (kasus baru) tahun 2007. Diperoleh dari http://www.dharmais.co.id/ index.php/cancer-statistic.html.

Siapkan Pengobatan Tradisonal di RS. (2014). Diperoleh 17 April 2017, dari http://kebijak ankesehatanindonesia.net/25-berita/berita/19 8-siapkan-pengobatan-tradisonal-di-rs.

Universitas Gajah Mada (2012, July 3). Terapi herbal kurang diminati untuk pengobatan kanker. Diperoleh 10 April 2017, dari https://www.ugm.ac.id/id/newsPdf/4353-tera pi.herbal.kurang.diminati.untuk.pengobatan. kanker.

Wang, L. (2017). Early diagnosis of breast cancer. Sensors, 17 (7), 1572. MDPI AG. doi: http:// dx.doi.org/10.3390/s17071572. 
Widyatuti, W. (2008). Terapi komplementer dalam keperawatan. Jurnal Keperawatan Indonesia, 12 (1), 53-57. doi: http://dx.doi.org/10.7454 /jki.v12i1.200.

Witdiawati, W., Rahayuwati, L., \& Sari, S. (2017). Enculturation in the life pattern of breast cancer patients: An ethno-nursing study on sundanese women. Jurnal Ners, 12 (1), 99107. doi: http://dx.doi.org/10.20473/jn.v12i1 .4143 .

World Health Organization. (2013). Breast cancer data. Diperoleh dari http://www.who.intl. org.
World Health Organization. (2017). Cancer. Diperoleh dari http://www.who.int/media centre/factsheets/fs297/en/

Yabroff, K.R., Lamont, E.B., Mariotto, A., Warren, J.L., Topor, M., Meekins, A., \& Brown, M.L. (2008). Cost of care for elderly cancer patients in the United States. Journal National Cancer Institute, 100 (9), 630-641. doi: 10.1093/jnci/djn103. 